\title{
The Economic in International Islamic Education Strategy Collaboration: A Rapid Review
}

\author{
Dian Cita Sari 1,", Ezi Apino², Ari Setiawan ${ }^{3}$, Nurzannah ${ }^{4}$, A. Hamid ${ }^{5}$, Afib Rulyansah ${ }^{6}$ \\ ${ }^{1}$ UIN Sultan Thaha Saifuddin Jambi, Indonesia \\ ${ }^{2}$ Yogyakarta State University, Yogyakarta, Indonesia \\ ${ }^{3}$ Universitas Sarjanawiyata Tamansiswa, Yogyakarta, Indonesia \\ ${ }^{4}$ Universitas Muhammadiyah Sumatera Utara, Medan, Indonesia \\ ${ }^{5}$ Universitas Serambi Mekkah, Aceh, Indonesia \\ ${ }^{6}$ Universitas Nahdlatul Ulama Surabaya, Surabaya, Indonesia \\ ${ }^{*}$ Corresponding author.Email:_diancita1@gmail.com
}

\begin{abstract}
This paper examine regarding the context throughout which Islam of Education economic techniques in global ventures may also be laid low with their global information, that shapes their dynamic talents. supported a carried out math synthesis of empirical insights collected in a completely big frame of literature, this paper examines more than one established order Islamic institution, and precise moderators on identical time. With fashions examined drawing on expertise from ten samples throughout 100 global access choices, this a rapid reviews empirical evidence for maximum component helping theoretical predictions of reassets global information, economic improvement ranges of host nations length that mild relationship among Islamic institution and economic method collaboration. Above all, contingency end result of precise information is extra essential courting than others. This paper demonstrates discourse nature courting and contributes insights into contingencies which have an impact at the effect of experience-primarily based totally dynamic functionality readying in an economic global Islamic institution setting.
\end{abstract}

Keywords: Economic, Islamic education, a rapid review.

\section{INTRODUCTION}

Theoretical views among world Moslem Education methodology collaboration data, rather like establishment movement approach paradigm [1], established order based totally essentially study [2], form learning principle [3], and dynamic abilities study [4] offer reasoning for the style and what world Moslem institution may have an impression on economic s' economic methodology in host nations. in addition, a thoughtful analysis of the discourse settings relating to institutional institution and contexts may financial gain anywhere the importance of world Moslem institution analysis and apply. This over one-contingency thought (i.e., on the identical time analyzing over one conditional settings), but, isn't generally conferred in gift analysis, that indicates the absence of grounded principle and via empirical statement supported rationalization of contingencies entreaty economic techniques theoretical framework projected and examined throughout this examine makes several noteworthy contributions to the residing literature. First, this paper solutions the selection for a additional context-primarily based mostly wholly experience of the economic in world Moslem Education methodology collaboration entreaty. Due to data doesn't perpetually recommend learning [5]. It's essential to grasp whether or not or not or currently not, what things economic s have discovered from data [6]

Preceding analysis have raised the priority that contingent problems rectangular degree important for world Moslem institution analysis [7], The economic methodology name has strategic and long-term outcomes due to succeeding course dependencies and influences the overseas subsidiary's overall performance[8]. Throughout this paper, economic method represents the proportion of economic at world access. International access employing a altogether in hand assignment with the subsequent complete management permits economic to paintings their methodology collaboration as they mirror on thought most acceptable, as opposition creating a punt native companions whose strategic intentions and behaviors rectangular degree very little or no understood and sometimes unpredictable.

This paper fills this important hole with exploitation conceptualizing profitable in Moslem establishment to strategically perform whereas a multinational access and 
with exploitation assaying however their result on profitable system is tentative on their environmentquality. This may above all manage with establishment length as a trademark of amount there to establishment three-dimensional degree of influence their experienceprimarily grounded utterly dynamic bents. Reassets from worldwide Moslem establishment is entered as a trademark relevancy in their dynamic bents, as a trademark moxie-primarily grounded complications utterly that redundant emblematize relevancy of bents, and additionally host sweetening position as a deputy for establishment anywhere Moslem institution is employed and rely on the activity [9].

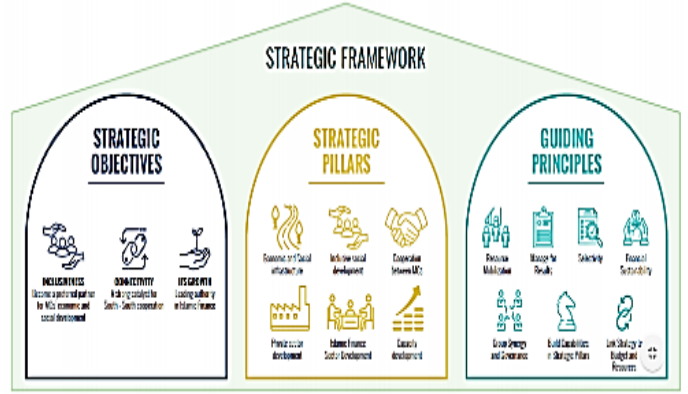

Figure 1. Strategic Framework (Source: ISDB)

Strategy Framework have 3 steps (Figure 1): Strategy objectives, strategy pillars, guiding principles. The frame of statistics relating to the profitable in world Moslem Education Strategy Collaboration. whereas a several experimenters have tried to attach form learning with collaboration ways in which and to link the worldwide Moslem establishment entered at some stage within approach of establishment movement to lessoning bents. [10]

In live performance of the important profitable decisions, profitable system supported world Moslem establishment is each an antecedent to big world overall performance and final results of Moslem establishment system. The loss of integration throughout analysis findings limits the contributions of gift day analysis on data and methodology to, and its usual result on, economic literature additionally as literature in connected disciplines like management and marketing. Previous a fast review have investigated troubles associated with economic in world Moslem Education access techniques and contributed sort of insights [11]. However, none of those each perpetually assesses the implications of experiential learning via its dynamic abilities or offers an entire experience of the discourse outcomes entreaty. Finally, this paper notably advances the literature. The findings found out that economic in world Moslem institution methodology collaboration have data fully pertains to the worldwide access and entreaty rests on Moslem institution data totally essentially dynamic abilities, consequently, this paper far-famed that economic study to put in their pertinency that condition.

\section{METHODOLOGY}

This examine used a fast review methodology. A fast review is a methodology accustomed describe the implications of the synthesis from numerous sorts of literature, anywhere the implications of the synthesis rectangular degree anticipated to help positive events in growing decisions [12]. This methodology square measure frequently aforesaid to be a changed form of systematic assessment that creates it ability to place operative it in abundant less time and use abundant less literature[13], than scientific assessment. moreover[14], named that changes rectangular degree generally created to gift approaches of the systematic assessment methodology in accomplishing fast reviews, a number of that rectangular degree English-most effective literature, ignoring grey literature, limiting literature get reassets, and utterly relating to one individual to settle on out literature or extract experience. The literature employed on this examine become searched via Google Scholar and Elsevier data. A literature get become disbursed on October 10, 2021.

\section{RESULT AND DISCUSSION}

This paper investigates how a worldwide Islamic education strategy partnership can influence an institution's global entry economic strategy. As a result, this work makes some theoretical and empirical contributions to economic education. To begin, combine a rapid review technique with another. This attempt yields a lot of interesting information. According to the economic size relationship, small economics are more likely to adopt a more comprehensive approach for accessing a worldwide level than substantial economics with a similar degree of international expertise. [15] Furthermore, our findings indicate that strategy of International Islamic Economic education derived from specific country is greater than impact of global operations in general economic [16]. It suggests that when economics education in several country gain practical experience, impacts of experiential learning [17]. This finding aligns with organizational theory, indicating that practical experience is more likely to impact effective deployment (e.g., specific and identifiable strategic decision-making processes) [18]

The rapid review findings show that developed countries are mitigate impact of international Islamic education on economic strategy. It is due to their institutional environment with a local partner because the institutional environment can protect the economy's impact over its subsidiary jointly owned with local partners. This rapid review reveals no substantial consequences of entry into developing countries, based on institution-based studies that revealed disparities between countries. This study implies that economists must update their expertise by learning local information for developing countries. An economy's proficiency 
depends on the individual circumstances of each developing country [19]. It claims that updating capabilities regularly helps economics discover and exploit possibilities more effectively and efficiently with right strategies [20].

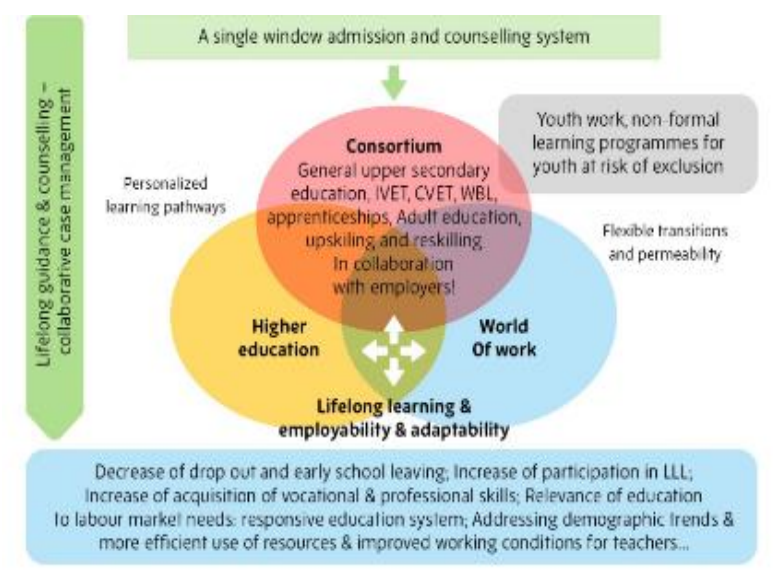

Figure 2. Strategy of International Islamic Economic Education (Source: ISDB)

From figure 2, describes justification in international entry is based on the fact that they have gained world of work experience. However, the arguments reported in this paper and empirical insights obtained from the study suggest that it is not the mere presence of international Islamic education in a strategic partnership that matters, but instead the economy's ability to utilize these in a specific context. As a result, their unique applicability to situation is equally critical. Motion that dynamic capabilities are persistent internationalization process of the economy and cannot be easily adapted across different worldwide Islamic education [21]. More typically case in significant economic consequences, this stickiness poses fewer internal economic problems and is distinguished by more persistence [22]. Furthermore, our findings suggest that economic qualities that apply to one international entry may not be equally applicable to another worldwide entry. [23] The relative impact of these contextual elements is an interesting finding of our rapid review study, which has important implications for context-related research. [24] This finding strengthens argument that an economic growth capability should be focused on reconfiguring Islamic education strategy resources by effectively learning from global experience, implying that economics must grow their capabilities through dynamic process to leverage expertise. [25]

In summary, essential consequences for managerial practice are that managers use their international Islamic education in strategic collaboration, resulting in the ability to deal with potential dependencies that can arise from the shared economy at global entry. Managers should be aware that the advantages of deploying capabilities are greater when the capabilities are inferred from host country-specific experience. [26] As a result, assuming that all experience-based dynamic capabilities same when entering global area would be erroneous.

Finally, the work described in this publication has numerous limitations, pointing to suggestions for future research. The first issue is that primary studies have limited access to contextual information. Because of incomplete data in primary studies, only ten publications were included in the rapid review data set, despite more than 100 papers being initially obtained from databases and evaluated for inclusion. Consequently, the data used in this study are inadequate to evaluate the different combinations of moderators, implying that future research should acquire direct data (either qualitative or historical data) to examine a broader range of contextual situations explicitly. Despite this, the rapid review study provided in this paper contributes to a better understanding of contextual factors by looking at numerous conditions. Future studies could further evaluate different interconnections of contextual variables (for example, the impact of an economy's home country on the dependency impact of host countries).

\section{CONCLUSION}

In conclusion, this have a look at investigates moderating outcomes of economic have precise contexts on the connection among global Islamic institution and economic method via way of means of statistically integrating empirical insights gathered in a huge frame of literature. By inspecting economic method selections at global entries, this paper gives proof displaying below what situations the experiential mastering is related to economic s' economic method for getting into a overseas market. The empirical outcomes in large part aid theoretical predictions that economic size, reassets of global Islamic institution, and economic development. In turn, this paper posits that a global Islamic institution in method collaboration undoubtedly pertains to its economic method at an global access and that this courting rests at the economics experience-primarily based totally abilties.

It is the economics potential to installation those abilties and their applicability that circumstance this courting. These theoretical and empirical contributions fill a number of crucial gaps within side extant literature for a couple of moderators concurrently and synthesizing numerous findings with a scientific have a look at. This fast assessment has succeeded in figuring out the economic in global Islamic institution collaboration method, how economic combine Islamic institution global used with method collaboration, and the way economic facilitate method, wherein those 4 matters mirror a small a part of the manner economic facilitate global Islamic institution method collaboration. The manner economic facilitate internationalization Islamic institution with method collaborate discovered on this have a look at tips at numerous troubles of development that is probably taken into consideration via way of 
means economic institution stakeholders, policymakers, or academic authorities.

\section{ACKNOWLEDGMENT}

The author teams are grateful to CEL KODELN, ICESEBE Comitee and Makasar State University (UNM).

\section{REFERENCES}

[1] Figueira-De-Lemos, F., \& Hadjikhani, A. (2014). Internationalization processes in stable and unstable market conditions: Towards a model of commitment decisions in dynamic environments. Journal of World Business, 49(3), 332-349.

[2] Peng, M. W., Wang, D. Y. L., \& Jiang, Y. (2008). An institution-based view of international business strat-egy: A focus on emerging economies. Journal of International Business Studies, 39(5), 920-936.

[3] Hotho, J. J., Lyles, M. A., \& Easterby-Smith, M. (2015). The mutual impact of global strategy and organ-izational learning: Current themes and future directions. Global Strategy Journal, 5(2), 85-112.

[4] Teece, D. J. (2014). A dynamic capabilities-based entrepreneurial theory of the multinational enterprise. Journal of International Business Studies, 45(1), 8-37.

[5] Argote, L. (2013). Organizational learning: Creating, retaining, and transferring knowledge (2nd ed.). New York: Springer.

[6] Hitt, M. A., Li, D., \& Xu, K. (2015). International strategy: From local to global and beyond. Journal of World Business, 51(1), 58-73.

[7] Li, P. Y., \& Meyer, K. E. (2009). Contextualizing experience effects in international business: A study of economic strategies. Journal of World Business, 44(4), 370-382.

[8] Uhlenbruck, K., Rodriguez, P., Doh, J., \& Eden, L. (2006). The impact of corruption on entry strategy: Evidence from telecommunication projects in emerging economies. Organization Science, 17(3), 402-416.

[9] Gelhard, C., Von Delft, S., \& Gudergan, S. P. (2016). Heterogeneity in dynamic capability configurations: Equifinality. Journal of Business Research, 69(11), 5272-5279.

[10] International Strategy Framework ISDB. 2020 https:/www.isdb.org/sites/default/files/media.pdf

[11] Luo, Y. (2000). Dynamic capabilities in international expansion. Journal of World Business, 35(4), 355-378. Luo, Y. (2001). Determinants of entry in an emerging economy: A multilevel approach. The Journal of Mangement Studies, 38(3), 443-472.

[12] Mcmillan, J. (2008). Market institutions. In S. N. Durlauf \& L. E. Blume (Eds.), The New Palgrave
Diction-ary of Economics (2nd ed.). London: Palgrave Macmillan.

[13] Meyer, K. E., \& Wang, Y. (2015). Transaction cost perspectives on alliances and joint ventures: Explanatory power and empirical limitations. In J. Larimo, N. Nummela, \& T. Mainela (Eds.), Elgar Handbook of International Alliances and Network Research. Cheltenham: Elgar.

[14] Singh, H., \& Kogut, B. (1989). Industry and competitive effects on the choice of entry mode. Academy of Management, 1989, 116-120.

[15] Somlev, I. P., \& Hoshino, Y. (2005). Influence of location factors on establishment and economic of foreign investments: The case of the Japanese manufacturing economic $\mathrm{s}$ in Europe. International Business Review, 14(5), 577-598.

[16] Delios, A., \& Beamish, P. W. (1999). International of Islamic Economic Education strategy: Transactional, institutional, and experience influences. Strategic Management Journal, 20(10), 915-933.

[17] Delios, A., \& Henisz, W. J. (2000). Japanese economic s' investment strategies in emerging economies. The Academy of Management Journal, 43(3), 305-323.

[18] Zollo, M., \& Winter, S. G. (2002). Deliberate learning and the evolution of dynamic capabilities. Organi-zation Science, 13(3), 351.

[19] Starbuck, W. H. (1985). Acting first and thinking later: Theory versus reality in strategic change. Organizational strategy and change (pp. 336-372)

[20] Teece, D. J., Pisano, G., \& Shuen, A. (1997). Dynamic capabilities and strategic management. Strategic Management Journal, 18(7), 509-533.

[21] Bingham, C. B., Eisenhardt, K. M., \& Furr, N. R. (2007). What makes a process a capability? Heuristics, strategy, and effective capture of opportunities. Strategic Entrepreneurship Journal, 1(1-2), 27-47.

[22] Wilden, R., \& Gudergan, S. (2015). The impact of dynamic capabilities on operational marketing and tech-nological capabilities: Investigating the role of environmental turbulence. Journal of the Academy of Marketing Science, 43(2), 181-199.

[23] Blomstermo, A., Sharma, D. D., \& Sallis, J. (2006). Choice of foreign market entry mode in service economic $s$. International Marketing Review, 23(2), 211-229.

[24] Erramilli, M. K. (1991). The experience factor in foreign market entry behavior of service economic s. Journal of International Business Studies, 22(3), 479-501.

[25] Wilden, R., Gudergan, S. P., Nielsen, B. B., \& Lings, I. (2013). Dynamic capabilities and performance: Strat-egy, structure and environment. Long Range Planning, 46(1), 96.

[26] Tihanyi, L., Griffith, D. A., \& Russell, C. J. (2005). The effect of cultural distance on entry mode choice, international diversification, and MNE performance: A a rapid review. Journal of International Busi-ness Studies, 36(3), 270-283. 